\title{
BROWNLIELLOIDEAE, A NEW SUBFAMILY IN THE TELOSCHISTACEAE (LECANOROMYCETES, ASCOMYCOTA)
}

\author{
S. Y. Kondratyuk ${ }^{1}$, I. Kärnefelt' ${ }^{2}$, A. Thell ${ }^{2}$, J. A. Elix ${ }^{3}$ \\ J. KIM ${ }^{4}$, A. S. KondratiuK ${ }^{5}$ and J.-S. Hur ${ }^{4}$ \\ ${ }^{1} M$. H. Kholodny Institute of Botany, \\ Tereshchenkivska str.2, 01004 Kiev,_Ukraine; E-mail:ksya_net@ukr.net \\ ${ }^{2}$ Biological Museum, Lund University, Box 117, SE-221 00 Lund, Sweden \\ ${ }^{3}$ Research School of Chemistry, Building 33, Australian National University \\ Canberra, ACT 0200, Australia \\ ${ }^{4}$ Korean Lichen Research Institute, Sunchon National University \\ 315 Mae-gok dong, Sunchon, 540-742, South Korea \\ ${ }^{5}$ Institute of Biology, Scientific Educational Centre, Taras Shevchenko National \\ University of Kiev, Volodymyrska str. 64/13, 01601 Kiev, Ukraine
}

(Received 7 May, 2015; Accepted 15 July, 2015)

Brownlielloideae, a new subfamily in the Teloschistaceae, is proposed based on phylogenetic analyses of nuclear ribosomal DNA and 12S SSU mitochondrial DNA sequences. The data indicates that the new subfamily includes eight genera, i.e. Brownliella, Marchantiana and six new genera proposed here, Lazarenkoella, Raesaeneniana, Streimanniella, Tarasginia, Tayloriella and Thelliana. Lecanora kobeana Nyl. is lectotypified and shown to be an older name for the type species of the genus Brownliella, B. aequata. In addition, a seventh new genus, Neobrownliella is proposed in the subfamily Teloschistoideae. This new genus and the new species, Thelliana pseudokiamae are described. 13 new combinations are proposed: Brownliella kobeana, Fulgogasparrea appressa, Lazarenkoella zoroasteriorum, Neobrownliella brownlieae, N. montisfracti, Raesaeneniana maulensis, Streimanniella burneyensis, S. kalbiorum, S. michelagoensis, S. seppeltii, Tarasginia tomareeana, T. whinrayi and Tayloriella erythrosticta.

Key words: Brownlielloideae, Lazarenkoella, Neobrownliella, new genera, Raesaeneniana, Streimanniella, Tarasginia, Tayloriella, Thelliana

\section{INTRODUCTION}

The number of genera in the Teloschistaceae has increased rapidly in recent years, from 10 in the phylogenetic study by Kärnefelt (1989) to presently ca 70. Many new segregates have been proposed by Arup et al. (2013a), Fedorenko et al. (2012) and Kondratyuk et al. (2013c, 2014a, b). The genus Caloplaca, previously one of the largest of all lichen genera comprising around 1,000 species, is now segregated into 42 genera spread over the entire family 
(Arup et al. 2013a, Kondratyuk et al. 2013c, 2014a, 2015). However, a number of these new genera have not been generally accepted (Miadłikowska et al. 2014).

Three major clades, corresponding the subfamilies Xanthorioideae, Caloplacoideae and Teloschistoideae were recently introduced within the Teloschistaceae (Arup et al. 2013b, Gaya et al. 2012), but only the latter has been described formally and considered to include 9 genera (Arup et al. 2013b). However, the delimitation of the subfamilies is still not settled since new species and genera continue to be discovered.

A fourth major clade is identified here and proposed as the new subfamily Brownlielloideae, positioned as a sister group to the subfamilies Teloschistoideae and Xanthorioideae (Fig. 1). The new genus Neobrownliella, belonging to the subfamily Teloschistoideae, is described below. It is segregated from the polyphyletic genus Brownliella, now included in the subfamily Brownlielloideae.

\section{MATERIALS AND METHODS}

The methods used for extraction, amplification and phylogenetic analyses are described in Fedorenko et al. $(2009,2012)$ and in Kondratyuk et al. $(2013 a, c, d, 2014 a, b)$. Genomic DNA was obtained from fresh samples and herbarium specimens. Voucher specimens included in the phylogenetic analyses are listed in Table 1.

Table 1

Specimens included into phylogenetic analysis with GenBank numbers (newly submitted data derived from this study are in boldface)

\begin{tabular}{|c|c|c|c|c|}
\hline Species name & Voucher/source & ITS1/ITS2 & LSU & $12 \mathrm{~S} \mathrm{mtSSU}$ \\
\hline Blastenia ferruginea & SK593, Kondratyuk et al. (2014a) & & & KJ023188 \\
\hline Blastenia ferruginea & Arup and Akelius (2009) & FJ866808 & & \\
\hline Blastenia ferruginea & Arup et al. $(2013 a)$ & \multicolumn{3}{|c|}{ KC179163 } \\
\hline Brigantiaea ferruginea & SK779, Kondratyuk et al. (2013c) & KF264622 & & KF264684 \\
\hline Brigantiaea ferruginea & SK780, Kondratyuk et al. (2013c) & KF264623 & & KF264685 \\
\hline Brownliella kobeana & $\begin{array}{l}\text { 120032, South Korea, Jeollanam-do, } \\
\text { Goheung-gun, Geumsan-myeon, } \\
\text { Gagum-do, Okryong coast, Ojeon-ri, } \\
34^{\circ} 26^{\prime} 16.9^{\prime \prime} \mathrm{N}, 127^{\circ} 07^{\prime} 15.4^{\prime \prime} \text { E, } \\
6 \text { m alt., on rock, } 17.04 .2012, \\
\text { U. Jayalal, J. S. Park \& J. A. Ryu }\end{array}$ & & & \\
\hline \multirow{3}{*}{ Brownliella kobeana } & 120032 (KoLRI 014623), this paper & KT456212 & KT456227 & KT456242 \\
\hline & $\begin{array}{l}\text { 130231, South Korea: Jeollanam-do, } \\
\text { Sinan-gun, Bigeum-myeon, Imjado, } \\
\text { nearby wharf Jinri, } 35^{\circ} 05^{\prime} 21.1^{\prime \prime} \mathrm{N}, \\
126^{\circ} 07^{\prime} 17.6^{\prime \prime} \text { E, } 11 \mathrm{~m} \text { alt., on rock, } \\
6.06 .2013 \text {, S. O. Oh, J. S. Park, J. J. Woo }\end{array}$ & & & \\
\hline & 130231 (KoLRI 018576), this paper & KT456213 & KT456228 & KT456243 \\
\hline
\end{tabular}


Table 1 (continued)

\begin{tabular}{|c|c|c|c|c|}
\hline Species name & Voucher/source & ITS1/ITS2 & LSU & $12 \mathrm{~S} \mathrm{mtSSU}$ \\
\hline Brownliella kobeana & $\begin{array}{l}\text { 130318, South Korea: Jeollanam-do, } \\
\text { Aphae-do, Sinan-gun, seaside, } \\
34^{\circ} 49^{\prime} 10.2^{\prime \prime} \text { N, } 126^{\circ} 21^{\prime} 38.7^{\prime \prime} \text { E, } \\
1 \text { m alt., on rock, } 7.06 .2013, \text { S. O. Oh, } \\
\text { J. S. Park, J. J. Woo } 130318 \\
\text { (KoLRI 018663), this paper }\end{array}$ & KT456214 & KT456229 & KT456244 \\
\hline Caloplaca cerina & $\begin{array}{l}\text { FNM 185, Fedorenko et al. } \\
(2009,2012)\end{array}$ & EU681284 & & EU680863 \\
\hline Caloplaca cerina & Gaya et al. (2012) & & JQ301549 & \\
\hline ‘Caloplaca' lateritia & SK232, Kondratyuk et al. (2013c) & & KF264663 & \\
\hline ‘Caloplaca' lateritia & SK878, Kondratyuk et al. (2013c) & KF264628 & & \\
\hline Catenaria desolata & Søchting et al. (2 & KF657317 & & KF657319 \\
\hline Eilifdahlia dahlii & $\mathrm{k}$ et al. & KJ02 & KJ021253 & KJ021279 \\
\hline Elenkiniana gloriae & SK613, Kondratyuk et al. (2014a) & KJ021322 & & KJ021283 \\
\hline Elenkiniana gloriae & SK611, Kondratyuk et al. (2014a) & & KJ021256 & \\
\hline Filsoniana australiensis & SK751, Kondratyuk et al. (2013c) & KF264631 & KF264665 & KF264691 \\
\hline Follmannia orthoclada & Arup et al. ( & KC1 & & \\
\hline Franwilsia bastowii & SK811, Kondr & KJ02 & KJ021258 & KJ021285 \\
\hline Fulgogasparrea appr & tal. $(2013 a)$ & КC179332 & & \\
\hline Fulgogasparrea decipioides & SK691, Kondratyuk et al. (2013c) & KF264643 & & KF264694 \\
\hline Fulgogasparrea decipioides & Arup et al. (2013a) & KC179333 & KC179269 & KC179608 \\
\hline Fulgogasparrea decipioides & SK689, Kondratyuk et & KF264644 & & KF264695 \\
\hline Golubk & SK4 & KJ13 & & \\
\hline Golubkovaea trachyphylla & Arup & KC179283 & KC179623 & \\
\hline Gyalolechia aurea & Arup et al. (2013a) & KC179434 & KC179196 & KC179530 \\
\hline Haloplaca sorediella & Arup et al. $(2013 a)$ & KC179293 & & \\
\hline Haloplaca suedae & Vondrák et al. (unpubl.) & HM582197 & & \\
\hline Honeggeria rosma & $\begin{array}{l}\text { Eichenberger et al. (unpubl. as } \\
\text { Xanthomendoza weberi) }\end{array}$ & AM697873 & & \\
\hline Honeggeria rosmariae & $\begin{array}{l}\text { Arup et al. ( } 2013 a \text { as Xanthomendoza } \\
\text { weberi) }\end{array}$ & KC179145 & KC179285 & KC179625 \\
\hline Huneckia pollinii & SK870, Kondratyuk et al. (2014a) & KJ021337 & KJ021266 & KJ021297 \\
\hline $\begin{array}{l}\text { Josefpoeltia parva } \\
\text { Josefpoeltia parva }\end{array}$ & $\begin{array}{l}\text { Eichenberger et al. (unpubl.) } \\
\text { Arup et al. (2013a) }\end{array}$ & AM697883 & & \\
\hline Kaernefia kaernefeltii & $\begin{array}{l}\text { Arup et al. (2013a) } \\
\text { SK919, Kondratyuk et al. (2013c) }\end{array}$ & KF264651 & $\begin{array}{l}\text { KC179204 } \\
\text { KF264679 }\end{array}$ & KF264702 \\
\hline
\end{tabular}

\section{Lazarenkoella zoroasteriorum}

Lazarenkoella zoroasteriorum

Marchantiana occidentalis
SK A45, Iran: Razavi Khorasan, $75 \mathrm{~km}$ route of Mashhad-Torbat-e Heidarieh, Bazehure, $35^{\circ} 47^{\prime} \mathrm{N}$, $59^{\circ} 22^{\prime}$ E, 1,500 m alt., 9.04.2013, M. Haji Moniri BH_S1 \& S. Parsa (KW-L), this paper

KT456215 KT456230 KT456245

SK A51, Iran: Razavi Khorasan, $75 \mathrm{~km}$ route of Mashhad-Torbat-e Heidarieh, Bazehure, $35^{\circ} 47^{\prime} \mathrm{N}$, $59^{\circ} 22^{\prime}$ E, 1,500 m alt., 9.04.2013, M. Haji Moniri BH_A1 \& S. Parsa (KW-L), this paper

KT456216 KT456231 KT456246

SK A55, Iran: Razavi Khorasan, Dargaz, Tandoureh National Park, Alibolagh, $37^{\circ} 32^{\prime} \mathrm{N}, 58^{\circ} 35^{\prime} \mathrm{E}$, $920 \mathrm{~m}$ alt., 9.05.2011, M. Haji Moniri A-4-K (KW-L), this paper $\begin{array}{lll}\text { KT456217 } & \text { KT456232 KT456247 }\end{array}$ SK981, Kondratyuk et al. (2014a)

KJ021227

KJ021268 KJ021303 
Table 1 (continued)

\begin{tabular}{|c|c|c|c|c|}
\hline Species name & Voucher/source & ITS1/ITS2 & LSU & $12 \mathrm{SmtSSU}$ \\
\hline Marchantiana occidentalis & SK982, Kondratyuk et al. (2014a) & KJ021228 & KJ021269 & KJ021304 \\
\hline Martinjahnsia resendei & Martin and Winka (2000) & AF101285 & & \\
\hline Martinjahnsia resendei & Arup et al. (2013a) & & KC179290 & KC179630 \\
\hline Mikhtomia oxnerii & 90117, Kondratyuk et al. (2014a) & KJ021233 & & KJ021311 \\
\hline Mikhtomia multicolor & SK A14, Kondratyuk et al. (2014a) & & KJ021272 & \\
\hline Neobrownliella brownlieae & SK831, Kondratyuk et al. (2013c) & KF264626 & KF264661 & KF264687 \\
\hline Neobrownliella br & SK83 & KF264627 & KF264662 & KF264688 \\
\hline Neobrownliella montisfracti & SK230, Kondratyuk et al. (2013c) & KF264624 & KF264659 & \\
\hline Niorma chrysophthalma & Eichenberger et al. (unpubl.) & AM292836 & & \\
\hline Niorma chrysophthalma & Gaya et al. (2012) & & JQ301576 & JQ301518 \\
\hline Pyrenodesmia alociza & SK747, Kondratyuk et al. (2014a) & KJ021239 & & KJ021313 \\
\hline Pyrenodesmia chalybaea & Gaya et al. (2012) & & 301550 & \\
\hline
\end{tabular}

Raesaeneniana maulensis Scutaria andina Seirophora blumii

Shackletonia sauronii Sirenophila bermaguiana Sirenophila bermaguiana Sirenophila eos Sirenophila eos Sirenophila gintarasii Sirenophila jackelixii Sirenophila jackelixii Sirenophila jackelixii Sirenophila maccarthii Sirenophila sp. 20 Sirenophila sp. 45 Squamulea squamosa Stellarangia elegantissima Streimanniella kalbiorum Streimanniella michelagoensis Streimanniella seppeltii Tarasginia whinrayi

\section{Tarasginia whinrayi}

SK993, Chile, 'Laguna del Maule', Maule, on rock. $35^{\circ} 54^{\prime} 28.4^{\prime \prime}$ S; $70^{\circ} 38^{\prime}$ 27.9" W; Alt.: ca 1,353 m a.s.1. Coll.: Wang, X. Y., Oh, S.-O. and Hur, J.-S., 30.01.2012. Holotype: KoLRI014500 (CL 120331), this paper SK994, Kondratyuk et al. (2014a) Arup et al. (2013a)

SK A65, Iran: Razavi Khorasan, Dargaz, Tandoureh National Park, Alibolagh, $37^{\circ} 32^{\prime} \mathrm{N}, 58^{\circ} 35^{\prime} \mathrm{E}$, $920 \mathrm{~m}$ alt., 9.05.2011, M. Haji Moniri Al_4 (KW-L), this paper

Arup et al. (2013a)

SK979, Kondratyuk et al. (2013c)

Arup et al. (2013a)

SK912, Kondratyuk et al. (2013c)

Arup et al. (2013a)

Arup et al. (2013a)

Arup et al. (2013a)

SK910, Kondratyuk et al. (2013c)

SK911, Kondratyuk et al. (2013c)

Arup et al. (2013a)

Arup et al. (2013a)

Arup et al. (2013a)

Arup et al. (2013a)

Arup et al. (2013a)

SK939, Kondratyuk et al. (2014a)

is SK971, Kondratyuk et al. (2014a)

SK855, Kondratyuk et al. (2014a)

SK A95, South Australia: Kangaroo

Island, summit of bluff $W$ of

Windmill Bay, $35^{\circ} 51^{\prime} \mathrm{S}, 138^{\circ} 07^{\prime} \mathrm{E}$, $40 \mathrm{~m}$ alt., on granite boulder in coastal heathland, 17.09.2012,

G. Kantvilas 506/12 (KW-L ex HO 567270), this paper

SK B02, South Australia: Kangaroo Island, 20.09.2012, G. Kantvilas 464/12 B. de Villiers (KW-L ex HO 567227), this paper
KT456218

KJ023182

KC179298

KT456233 KT456248 KJ023184

KC179242 KC179581

KT456219

KC179120

KT456234 KT456249

KC179241 KC179580

KF264706

KC179299

KF264656

KC179300

KC179302

KC179303

KF264655

KC179304

KC179306

KC179307

KC179125

KC179310

KJ021225

KJ021226

KJ021229

KC179245 KC179584

KC179246 KC179585

KC179248 KC179587

KF264683 KF264707

KF264708

KC179249 KC179588

KC179250 KC179589

KC179252 KC179591

KC179254 KC179593

KJ023183 KJ021300

KJ023185 KJ021301

KJ023186 KJ021305

KT456220 KT456235 KT456250

$\begin{array}{lll}\text { KT456221 KT456236 KT456251 } & \text { KT }\end{array}$ 
Table 1 (continued)

\begin{tabular}{|c|c|c|c|c|}
\hline Species name & Voucher/source & ITS1/ITS2 & LSU & $12 \mathrm{~S} \mathrm{mtSSU}$ \\
\hline Tassiloa digitaurea & SK A34, Kondratyuk et al. (2015) & КР096222 & & КР096224 \\
\hline Tayloriella erythrosticta & $\begin{array}{l}\text { SK 817, Western Australia, } \\
\text { 9.01.2004, S. Y. Kondratyuk } 20435 \\
\text { (LD), this paper }\end{array}$ & KT456222 & KT456237 & KT456252 \\
\hline Tayloriella erythrosticta & $\begin{array}{l}\text { SK 814, Western Australia, } \\
\text { 9.01.2004, S. Y. Kondratyuk } 20435 \\
\text { (KW-L), this paper }\end{array}$ & KT456223 & KT456238 & KT456253 \\
\hline Tayloriella erythrosticta & $\begin{array}{l}\text { SK 819, Western Australia, } \\
\text { 9.01.2004, S. Y. Kondratyuk } 20435 \\
\text { (LD), this paper }\end{array}$ & KT456224 & KT456239 & KT456254 \\
\hline Teloschistes flavicans & $\begin{array}{l}\text { FNM-139, Fedorenko et al. } \\
(2009,2012)\end{array}$ & EU681363 & & EU680955 \\
\hline Teloschistopsis bonae-spei & Arup et al. (2013a) & KC179324 & KC179257 & KC179596 \\
\hline Teloschistopsis eudoxa & Arup et al. (2013a) & KC179322 & KC179258 & КC179597 \\
\hline Thelliana pseudokian & $\begin{array}{l}\text { SK925, South Australia, Quorn, } \\
\text { 17.01.1999, I. Kärnefelt 994101 } \\
\text { (LD 1101337), this paper }\end{array}$ & KT456225 & KT456240 & KT456255 \\
\hline Thelliana pseudokiamae & $\begin{array}{l}\text { SK926, South Australia, Quorn, } \\
\text { 17.01.1999, I. Kärnefelt 994101 } \\
\text { (LD 1101337), this paper }\end{array}$ & KT456226 & KT & KT456256 \\
\hline Villophora & Arup et al. (2013a) & KC179325 & KC179266 & KC179606 \\
\hline Wetmoreana texana & SK537, Kondratyuk et al. (2013c) & KF264657 & & KF264710 \\
\hline Wetmoreana texana & SK536, Kondratyuk et al. (2013c) & KF264658 & & KF264711 \\
\hline Wetmoreana texana & Arup et al. (2013a) & KC179337 & KC179273 & KC179612 \\
\hline Xanthomendoza $n$ & FNM 215, Fedorenko & EU681349 & & \\
\hline Xanthomendoza mendoza & FNM 069, Fedorenko et al. (2009) & & & EU680939 \\
\hline Xanthomendoza mendoza & Arup et al. $(2013 a)$ & & KC179281 & \\
\hline Xanthoria parietina & $\begin{array}{l}\text { FNM-177, Fedorenko et al. } \\
(2009,2012)\end{array}$ & EU681289 & & EU680868 \\
\hline Xanthoria parietina & Gaya et al. (2012) & & JQ301589 & \\
\hline
\end{tabular}

Three regions targeted for this study were: $0.6 \mathrm{~kb}$ of the ITS1/ITS2 region using the primers ITS1 and ITS4 (White et al. 1990) and the primer ITS1F (Gardes and Bruns 1993), $0.8 \mathrm{~kb}$ of the $28 \mathrm{~S}$ LSU using the primer LR5 (Vilgalys and Hester 1990), and $0.8 \mathrm{~kb}$ of $12 \mathrm{StSSU}$ using the primers mtSSU1$\mathrm{mtSSU} 3 \mathrm{R}$ and $\mathrm{mtSSU} 2 \mathrm{R}$ (Fedorenko et al. 2009, 2012).

Automated reaction clean up and visualisation of the results were performed at the Lichen Bioresource Genome Sequencing and Analysis Core Facility of the Korean Lichen Research Institute, Sunchon National University, South Korea. Sequence fragments were subjected to BLAST searches for the first verification of their identities. They were assembled and edited using Sequencher version 4.8 (Gene Codes Corporation, Ann Arbor, MI), and aligned manually.

The phylogenetic analyses of the manually aligned sequences were performed with PAUP version 4.0b10 (Swofford 2002). Trees were calculated using the general heuristic search option, maximising the number of saved trees to 1,000 , whereas gaps were treated as missing characters. Bootstrap analyses 
with 1,000 replicates were performed using the same settings. Support values of 50 or above are marked in the consensus tree (Fig. 1). PM, LM and ME were performed.

The morphological results are based mainly on studies of our own specimens, collected during field trips in Europe, Asia, Australia and New Zealand. For anatomical studies, lichen sections were prepared manually or using a Kryomat, Leitz freezing microtome, mounted in water or in lactophenol cotton blue and studied through a Zeiss Axioscope light microscope.

\section{RESULTS}

The separate analyses

The ITS analysis included 96 specimens of 61 species and a total of 550 positions of which 357 were informative. The LSU analysis included 81 specimens representing 52 species and a total of 762 positions of which 194 were informative, whereas the $12 \mathrm{~S} \mathrm{mtSSU}$ analysis included 84 specimens of 50 species and a total of 744 positions of which 229 were informative.

The seven genera proposed below, i.e. Lazarenkoella, Neobrownliella, Raesaeneniana, Streimanniella, Tarasginia, Tayloriella, and Thelliana reveal strong support in the separate analyses (not shown in Figure 1). The four genera Marchantiana, Raesaeneniana, Streimanniella, and Thelliana form a sister group to the remaining part of the Teloschistaceae in the separate analyses, while the other genera described here, i.e. Lazarenkoella, Neobrownliella, Tarasginia, and Tayloriella, are positioned within the Teloschistoideae.

\section{The combined analysis}

The combined analysis of nuclear ITS, LSU and $12 \mathrm{~S} \mathrm{mtSSU}$ data sets included 78 specimens of 55 species and a total of 2,056 positions of which 787 were informative.

All seven genera, proposed below, i.e. Lazarenkoella, Neobrownliella, Raesaeneniana, Streimanniella, Tarasginia, Tayloriella, and Thelliana are strongly supported in the combined analysis (Fig. 1). Three of the genera (Marchantiana, Streimanniella, Raesaeneniana) form three single clades, whereas five of the genera (Brownliella, Lazarenkoella, Tarasginia, Tayloriella, Thelliana) are positioned in a second, weakly supported clade of the Brownlielloideae. However, the genus Neobrownliella, proposed below, is doubtlessly a member of the Teloschistoideae (Fig. 1).

The Brownlielloideae is preliminarily divided into two weakly supported clades, the Brownliella clade and the Marchantiana clade. The Brownliella 
clade includes five genera, i.e. Brownliella, Lazarenkoella, Tarasginia, Tayloriella and Thelliana, while the Marchantiana clade includes the genera Marchantiana, Raesaeneniana and Streimanniella.

\section{Taxonomy}

Seven new genera are proposed for the strongly supported monophyletic branches; i.e. Lazarenkoella for the Asian species Caloplaca zoroasteriorum; Neobrownliella for the Australian Caloplaca brownliae group; Raesaeneniana for the South American species Marchantiana maulensis; Streimanniella for the Australian Caloplaca michelagoensis group; Tarasginia for the Australian Caloplaca whinrayi group; Tayloriella for the Australian species Caloplaca erythrosticta; and Thelliana for the Australian species Thelliana pseudokiamae.

Examined material in the present phylogeny study shows that the genus Brownliella forms a separate subfamily in the Teloschistaceae together with 7 additional genera, namely Lazarenkoella, Marchantiana, Raesaeneniana, Streimanniella, Tayloriella, Tarasginia and Thelliana (Fig. 1). Six strongly supported clades were identified and are proposed here as new genera. A strong branch comprising two species was discovered in the genus Brownliella within the subfamily Teloschistoideae and is proposed here as the genus Neobrownliella.

Brownlielloideae S. Y. Kondr., Kärnefelt, Elix et A. Thell, subfam. nova MycoBank no.: MB 813890.

Type genus: Brownliella S. Y. Kondr., Kärnefelt, Elix, A. Thell et J.-S. Hur.

Differs from the subfamilies Teloschistoideae, Caloplacoideae and Xanthorioideae in the following mtSSU DNA sequence, in usually having a T - not an A - in the sequence AGATTAGATTATATTTCTTCTA, and together with the subfamily Xanthorioideae, differs from the subfamilies Caloplacoideae and Teloschistoideae in usually having an A - not a G (C) - in the sequence TTCTAGGTAGAGTAATGATAACGACA, and from Teloschistoideae and Xanthorioideae in having an A rather than the usual G, as well as from Caloplacoideae in having a $G$ or $T$ rather than a $C$ in the sequence TATGATAGAAGGGACTAAGATAAG.

The new subfamily forms a fourth main branch of the Teloschistaceae. In our analysis, the subfamily Caloplacoideae appears as a sister group to the three other subfamilies (Fig. 1), with Brownlielloideae a sister group of Xanthorioideae and Teloschistoideae. The Brownlielloideae is preliminary divided into two clades, firstly the Brownliella clade including the genera 
Brownliella, Lazarenkoella, Tarasginia, Tayloriella and Thelliana and secondly, the Marchantiana clade including the genera Marchantiana, Raesaeneniana and Streimanniella.

The Brownlielloideae occurs mainly in the Southern Hemisphere, in particular, on the Australian continent. A few species are also known from the Northern Hemisphere.

The Marchantiana branch of the Brownlielloideae clade is well supported and positioned separately from the Teloschistoideae, Caloplacoideae and Xanthorioideae in all cases of the analysis, while the Brownliella clade is sometimes positioned in the Teloschistoideae if only genera from this subfamily are included. If the subfamily Caloplacoideae is included in the phylogenetic analysis, the position of Brownliella in the Brownlielloideae becomes stable.

The new subfamily is named after the genus Brownliella S. Y. Kondr., Kärnefelt, Elix, A. Thell et J.-S. Hur, a genus which, when described, was included in the subfamily Teloschistoideae, albeit in an isolated position relative to the remainder of the subfamily (Kondratyuk et al. 2013c, 2014a).

\section{Brownliella S. Y. Kondr., Kärnefelt, Elix, A. Thell et J.-S. Hur Acta Bot. Hung. 55(3-4): 265 (2013)}

Type species: Brownliella aequata (Hue) S. Y. Kondr., Kärnefelt, A. Thell, Elix, J. Kim, A. S. Kondratyuk et J.-S. Hur, Acta Bot. Hung. 55(3-4): 271 (2013); Caloplaca aequata (Hue) Zahlbr., Cat. Lich. Univ. 7: 211 (1930) [1931]. - Basionym: Lecanora aequata Hue, Ann. Mycol. 13(2): 78 (1915), "in Corea quartzicolam legit R. P. Faurie in Kang-ouen-to, n. 4289 et 4819, ac in Fusan n. 4395, Julio et octobri 1901" (PC? not seen).

= Brownliella kobeana (Nyl.) S. Y. Kondr., Kärnefelt, Elix, A. Thell et J.-S. Hur - Basionym: Lecanora kobeana Nyl., Lichenes Japoniae: 36. 1890. इ Caloplaca kobeana (Nyl.) Zahlbr., Cat. Lich. Univ. 7: 241 (1930) [1931].

Brownliella aequata was selected as the type of this genus when the species was considered to have a western Pacific distribution. It was originally described as Lecanora aequata from Korea by Hue (1915) and subsequently from Australia by Kondratyuk and coauthors as 'Caloplaca' brownlieae in 2011 (Lumbsch et al. 2011). At that time 'Caloplaca' brownlieae was believed to be a superfluous name, however, its status as an independent species was subsequently supported by molecular data (see below).

Australian collections of Brownliella appeared nested within the FilsonianaBrownliella clade of the subfamily Teloschistoideae (Kondratyuk et al. 2013c).

Both the morphology and molecular phylogeny of Brownliella aequata have since been revised and Hue's Lecanora aequata was found to be a latter synonym of Lecanora kobeana Nyl. 
Furthermore, phylogenetic analyses using ITS1/ITS2 and LSU nrDNA and 12S SSU mtDNA sequences confirmed that the Asian Brownliella kobeana was not conspecific with the Australian 'Caloplaca' brownlieae. According to a combined data set, the Asian material of Brownliella was positioned within the Brownlielloideae clade, whereas the Australian material of 'Caloplaca' brownlieae remained in the subfamily Teloschistoideae, and here proposed to constitute the new genus, Neobrownliella.

\section{Lazarenkoella S. Y. Kondr., Kärnefelt, A. Thell, Elix et J.-S. Hur, gen. nova}

MycoBank no.: MB 813891.

Thallus crustose, areolate to squamulose, sometimes richly sorediate/blastidiate, whitish. Apothecia zeorine; cortical layer of thalline exciple paraplectenchymatous; true exciple paraplectenchymatous; asci with 8(-12-16) ascospores. Apothecial disc with anthraquinones of the parietin chemosyndrome.

Type species: Lazarenkoella zoroasteriorum (S. Y. Kondr. et M. Haji Moniri) S. Y. Kondr., Kärnefelt, A. Thell, Elix, J. Kim, A. S. Kondratiuk et J.-S. Hur.

Thallus small, usually indistinct, consisting of tiny, scattered whitish areoles or squamules, sometimes richly sorediate, with very rare, small apothecia. Blastidia or soredia regularly rounded, rarely forming irregular conblastidia. Apothecia zeorine; cortical layer of thalline exciple paraplectenchymatous, cell lumina 7.5-12.5 $\mu \mathrm{m}$ wide (Massjukiella type, sensu Fedorenko et al. 2012); true exciple paraplectenchymatous; asci with 8(-12-16) ascospores; ascospores ellipsoid with rather narrow septa; disc K+ purple (with anthraquinones of the parietin chemosyndrome), thallus $\mathrm{K}-$.

Ecology: The single species occurs on deciduous trees (Prunus sp. and Populus spp.), often along roadside or close to waterfalls, or reservoirs.

Distribution: Lazarenkoella zoroasteriorum is known from several localities in Iran and Uzbekistan.

Etymology: The generic name is in the honour of the Ukrainian bryologist and lichen-collector Andrij S. Lazarenko (1901-1979) who worked in both Kyiv and Lviv, and provided important collections from several central Asian countries.

Taxonomic notes: The genus Lazarenkoella is morphologically and anatomically similar to some species of Calogaya (particularly the Calogaya lobulata group, i.e.: sect. Xanthoriella of the genus Caloplaca sensu Steiner and Poelt (1982), including Calogaya polycarpoides and C. persica), as well as to some species representatives of Scythioria and 'Caloplaca' (see also Kondratyuk et al. 
2013a, b). The genera, Calogaya and Scythioria, are members of the subfamily Xanthorioideae, while Caloplaca belongs to the Caloplacoideae.

It will be some time before we know how many species can be included in Lazarenkoella. Furthermore, additional species of Calogaya and Scythioria should be included in future analyses to delineate the borders between these genera.

\section{Marchantiana S. Y. Kondr., Kärnefelt, Elix, A. Thell et J.-S. Hur Acta Bot. Hung. 56(1-2): 103 (2014)}

Type species: Marchantiana occidentalis (Elix, S. Y. Kondr. et Kärnefelt) S. Y. Kondr., Kärnefelt, Elix, A. Thell, J. Kim, A. S. Kondratiuk et J.-S. Hur.

Originally Marchantiana included five Australian species (i.e. M. burneyensis (S. Y. Kondr. et Kärnefelt) S. Y. Kondr., Kärnefelt, A. Thell, Elix, J. Kim, A. S. Kondratiuk et J.-S. Hur, M. kalbiorum (S. Y. Kondr. et Kärnefelt) S. Y. Kondr., Kärnefelt, A. Thell, Elix, J. Kim, A. S. Kondratiuk et J.-S. Hur, M. michelagoensis (Elix, S. Y. Kondr. et Kärnefelt) S. Y. Kondr., Kärnefelt, A. Thell, Elix, J. Kim, A. S. Kondratiuk et J.-S. Hur, M. occidentalis (Elix, S. Y. Kondr. et Kärnefelt) S. Y. Kondr., Kärnefelt, A. Thell, Elix, J. Kim, A. S. Kondratiuk et J.-S. Hur and M. seppeltii (S. Y. Kondr. et Kärnefelt) S. Y. Kondr., Kärnefelt, A. Thell, Elix, J. Kim, A. S. Kondratiuk et J.-S. Hur), as well as M. maulensis S. Y. Kondr. et J.-S. Hur from South America (Kondratyuk et al. 2014a). The genus so defined, was quite diverse in both morphological and chemical characters, but nevertheless strongly supported by the analysis based on the combined molecular data set. Marchantiana occidentalis is characterised by having biatorine or rarely zeorine apothecia with a pseudoprosoplectenchymatous true exciple, and in containing ascomatic acid and related dibenzofurans. It should also be mentioned that the mitochondrial DNA data indicated that M. occidentalis occupied a separate and rather distant position from other Marchantiana species, but all of the species form a strongly supported monophyletic branch using the combined data set (Kondratyuk et al. 2014a).

Neobrownliella S. Y. Kondr., Elix, Kärnefelt et A. Thell, gen. nova MycoBank no.: MB 813892.

Thallus continuous or areolate, yellow to reddish orange or pink; cortical layer paraplectenchymatous. Apothecia immersed to biatorine; true exciple poorly developed; conidia narrowly bacilliform; constituents: anthraquinones of the parietin chemosyndrome. 
Type species: Neobrownliella brownlieae (S. Y. Kondr., Elix et Kärnefelt) S. Y. Kondr., Elix, Kärnefelt et A. Thell. - Basionym: Caloplaca brownlieae S. Y. Kondr., Elix et Kärnefelt, Phytotaxa 18: 28 (2011). Type: Australia. New South Wales: above Lake Eucumbene, on granite boulder, coll.: Brownlie, April 1969 (holotype: MEL 1023635).

Thallus continuous to areolate, sometimes becoming sublobate in the peripheral zone, dull pink, brownish pink to bright orange or reddish orange, cortical layer palisade paraplectenchymatous. Apothecia immersed or rarely adnate, biatorine, true exciple very thin. Ascospores polaribilocular, 8 per ascus, usually with only (2-)4-6 spores well developed, rather small. Conidia bacilliform to narrowly bacilliform. Thallus and apothecia $\mathrm{K}+$ purple; constituents: anthraquinones of the parietin chemosyndrome or parietin with additional gyrophoric, ovoic and lecanoric acids, xanthorin and erythroglaucin (in small amount).

Etymology: The name was chosen to illustrate the relationship with the genus Brownliella.

Taxonomic notes: Neobrownliella differs from the Caloplaca in having a continuous or areolate thallus containing anthraquinones, in having a palisade paraplectenchymatous cortical layer, and in lacking a thick palisade cortical layer on the underside of the thalline exciple. Unlike the other six genera proposed in this study, Neobrownliella is nested in the subfamily Teloschistoideae (Fig. 1).

The genus Neobrownliella is morphologically similar to the Northern Hemisphere Brownliella, but differs from the latter in having an Australian distribution, as well as in molecular characters.

At present Neobrownliella includes two species, Neobrownliella brownlieae and N. montisfracti (Kondratyuk et al. 2007, Lumbsch et al. 2011), both exclusively Australian. The widely distributed 'Brownliella' cinnabarina may also belong here, but the phylogenetic position of that species has yet to be confirmed.

Raesaeneniana S. Y. Kondr., Kärnefelt, A. Thell, Elix et J.-S. Hur, gen. nova

MycoBank no.: MB 813893.

Thallus crustose, knobby to microlobulate, dull brownish orange to dull reddish brown. Apothecia lecanorine, disc dark reddish brown to orange-brown; proper exciple present only in the basal portion; hymenium and subhymenium with numerous oil droplets and irregular oil inclusions. 
Type species: Raesaeneniana maulensis (S. Y. Kondr. et J.-S. Hur) S. Y. Kondr., Elix, Kärnefelt et A. Thell.

Thallus crustose, consisting of aggregations of plane, more or less flattened or rounded microlobules, dull brownish orange to dull reddish brown. Upper surface knobby to microlobulate; lower cortex paraplectenchymatous, with very small cell lumina. Apothecia lecanorine, thalline margin microcrenulate, persistent, dull brownish orange, concolorous with thallus; disc dark reddish brown to orange-brown; proper exciple not developed in the lateral portion, often only present in the basal portion; hymenium and subhymenium with numerous oil droplets and irregular oil inclusions; asci 8-spored, but only with 1-2(-4) bipolar ascospores together with simple, aborted ascospores, bipolar ascospores with medium sized septa in water, becoming much wider in $\mathrm{K}$.

Etymology: The genus is named in the honour of the Finnish lichenologist Veli (Johannes Paavo Bartholomeus) Räsänen (1888-1953) who made many collections of Teloschistaceae from South America and other parts of the world.

Ecology: On rock surfaces, detritus or bryophytes.

Distribution: This monotypic genus is only known from South America.

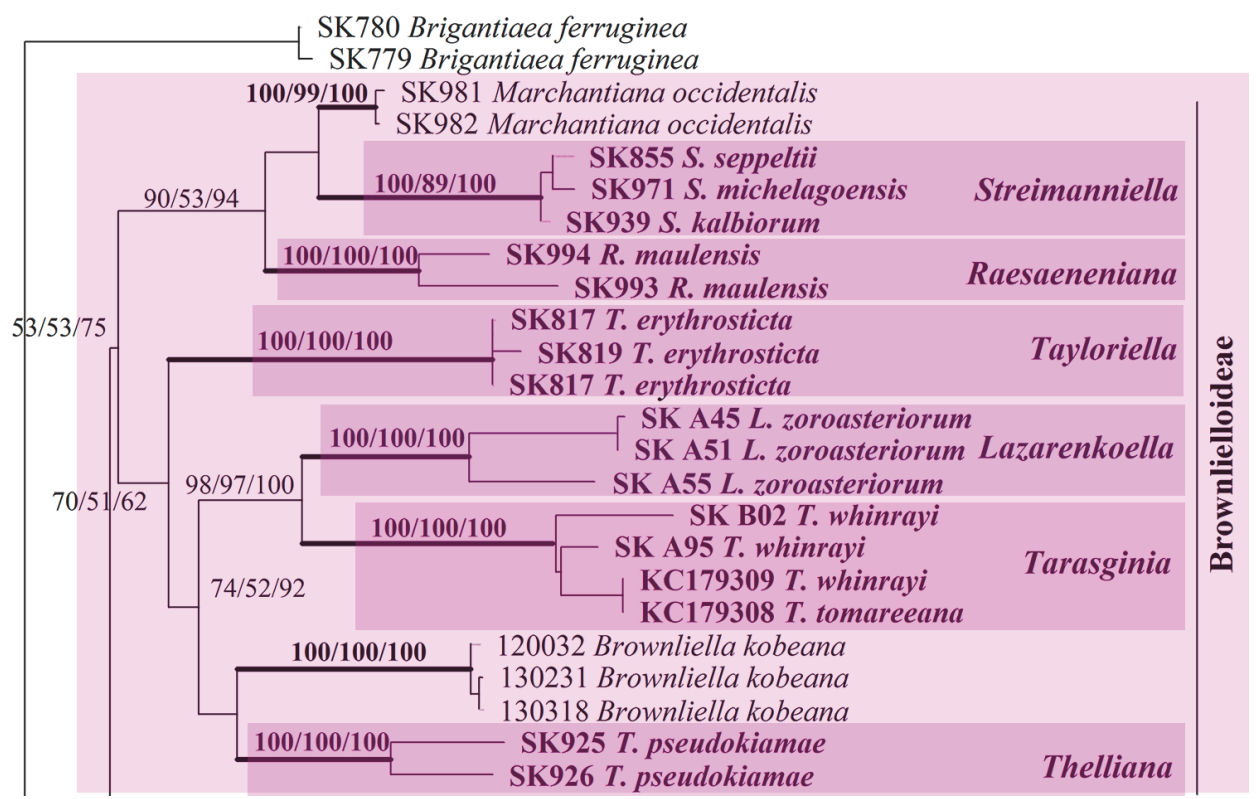

Fig. 1. Phylogenetic tree based on ITS, LSU and mtSSU-sequences, showing the position of the Brownlielloideae 


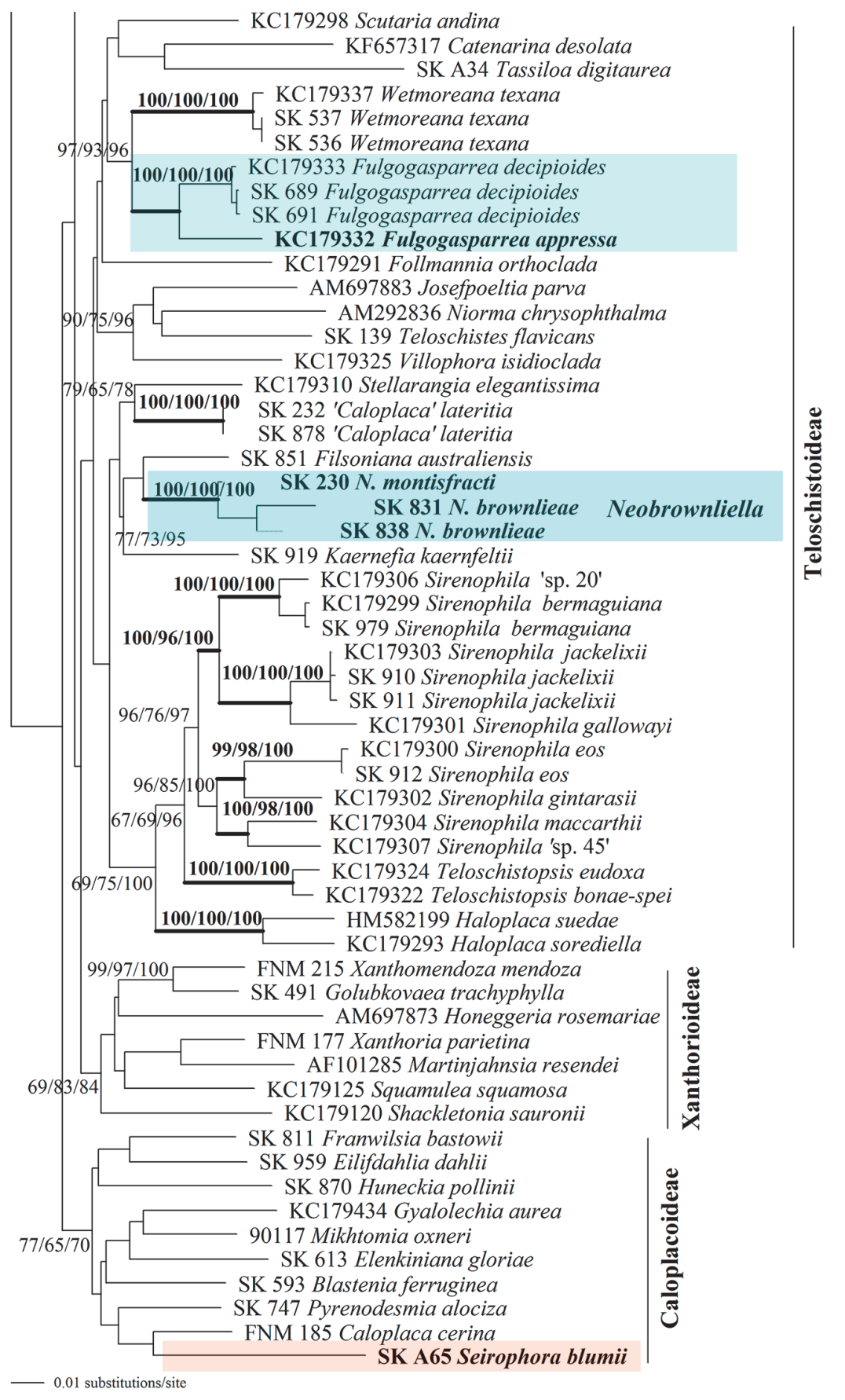

Fig. 1. (continued from the previous page) 
Taxonomic notes: Raesaeneniana is similar to the Southern Hemisphere genera Austroplaca and Villophora and the Antarctic species, 'Caloplaca' iomma Olech et Søchting, from which it differs in morphology, the size and shape of the ascospores (see also Kondratyuk et al. 2014a) and in its position in the phylogenetic tree of the Teloschistaceae. The genus Austroplaca is a member of the Xanthorioideae, whereas Villophora belongs to the Teloschistoideae and Raesaeneniana belongs to the Brownlielloideae.

Given the rather large areoles with a very uneven, knobby upper surface, Raesaeneniana may also resemble some species of Squamulea (i.e.: S. squamosa (B. de Lesd.) Arup, Søchting et Frödén) and Xanthocarpia (i.e.: X. jerramungupensis (S. Y. Kondr. et Kärnefelt) S. Y. Kondr., Kärnefelt, A. Thell, Elix, J. Kim, A. S. Kondratiuk et J.-S. Hur) of the Xanthorioideae and species in the genera Variospora and 'Caloplaca' (i.e. 'Caloplaca' grimmiae (Nyl.) H. Olivier and 'Caloplaca' hallasanensis S. Y. Kondr., S.-O. Oh et J.-S. Hur, etc.) in the subfamily Caloplacoideae.

Streimanniella S. Y. Kondr., Kärnefelt, A. Thell, Elix et J.-S. Hur, gen. nova

MycoBank no.: MB 813894.

Thallus continuous or areolate, from white to grey or dark brownish grey; cortical layer thin, paraplectenchymatous. Apothecia lecanorine or zeorine; true exciple paraplectenchymatous or composed of 'textura intricata'; ascospores bipolar becoming brownish or blackish in the asci or multiseptate; constituent: neochloroemodin.

Type species: Streimanniella michelagoensis (Elix, S. Y. Kondr. et Kärnefelt) S. Y. Kondr., Kärnefelt, A. Thell, Elix, J. Kim, A. S. Kondratiuk et J.-S. Hur.

Thallus continuous or areolate, from white to grey or dark brownish grey. Apothecia lecanorine or zeorine; thalline margin concolorous with the thallus, with a very thin paraplectenchymatous cortical layer; disc varying in colour from blackish, dirty brown, orange brown to concolorous with the thallus; true exciple paraplectenchymatous or composed of 'textura intricata'; paraphyses richly branched, not swollen, brownish towards the tips; asci 2-4-6-8-spored; ascospores bipolar, becoming brownish or blackish in the asci, or multiseptate. Epihymenium $\mathrm{K}+$ purple; constituent: neochloroemodin.

Etymology: The genus is named in honour of the Australian bryologist and lichen collector Heinar Streimann (1938-2001) (Canberra, Australia) who has made many collections from the Australian continent.

Taxonomic notes: Streimanniella differs from Caloplaca s. str. in having a continuous or areolate thallus containing neochloroemodin, with a much 
thinner paraplectenchymatous cortical layer, in lacking a thick palisade cortical layer on the underside of the thalline exciple of apothecia, and in lacking apically swollen paraphyses and anthraquinones of the parietin chemosyndrome.

Streimanniella is similar to the Australian genus Marchantiana, but differs in having lecanorine or zeorine apothecia, a paraplectenchymatous true exciple or composed of 'textura intricata', in the presence of neochloroemodin, and in the absence of ascomatic acid and related dibenzofurans.

Streimanniella includes four Australian species, namely S. burneyensis, $S$. kalbiorum, S. michelagoensis, and S. seppeltii. The Streimanniella seppeltii group, characterised by multiseptate ascospores, is in need of further revision using molecular methods.

Tarasginia S. Y. Kondr., Kärnefelt, A. Thell, Elix et J.-S. Hur, gen. nova MycoBank no.: MB 813895.

Thallus distinctly lobate, lemon yellow to dull yellow; lobes plane or convex, cortical layer paraplectenchymatous. Apothecia zeorine, disc bright red to brownish orange; hymenium and subhymenium with oil droplets; true exciple comprising hyphae and matrix; conidia broadly bacilliform; constituents: anthraquinones of the parietin chemosyndrome.

Type species: Tarasginia whinrayi (S. Y. Kondr. et Kärnefelt) S. Y. Kondr., Kärnefelt, A. Thell, Elix, J. Kim, A. S. Kondratiuk et J.-S. Hur.

Thallus distinctly lobate at the margin, verrucose to warty in the central part, lemon yellow or greenish yellow to dull yellow, occasionally reddish yellow or orange; lobes plane or convex, cortical layer paraplectenchymatous. Apothecia zeorine, attenuated at the base, disc bright red or red-orange to brownish red or brownish orange; hymenium and subhymenium with oil droplets; true exciple comprising hyphae and matrix; paraphyses distinctly swollen towards the tips, often with oil droplets; conidia widely bacilliform; constituents: anthraquinones of the parietin chemosyndrome.

Etymology: The genus is named in the honour of the Tasmanian lichenologist Gintaras Kantvilas, who made many collections of Teloschistaceae in Tasmania and other regions of Australia.

Taxonomic notes: Tarasginia differs from Caloplaca s. str. in having a lobate thallus containing anthraquinones, and in lacking a thick palisade cortical layer on the underside of the thalline exciple of the apothecia, and its position in the subfamily Brownlielloideae. 
Given the lobate thalli Tarasginia is similar to the Northern Hemisphere genus Fulgogasparrea and the Southern Hemisphere genera Filsoniana and Follmanniana, all three belonging to subfamily Telochistoideae, and the Northern Hemisphere genera Elenkiniana, Gyalolechia s. str. and Variospora in subfamily Caloplacoideae and the Southern Hemisphere genera Austroplaca, Gondwania and Verrucoplaca in the Xanthorioideae. Tarasginia differs from all these genera in having its centre of distribution on the Australian continent, and its phylogenetic position in the new subfamily Brownlielloideae.

The species of Tarasginia were previously included in the genus Sirenophila in subfamily Teloschistoideae according to ITS1/IT2 nrDNA data (Arup et al. 2013a). However, when LSU nrDNA and 12S SSU mtDNA sequences were included in the analysis, this genus forms a strongly supported clade within the Brownlielloideae (Fig. 1).

Tarasginia includes two Australian species, T. whinrayi and T. tomareeana (Kondratyuk et al. 2007). A third species, referred to as 'Sirenophila sp. 45 ' by Arup et al. (2013a) presumably belongs here.

Tayloriella S. Y. Kondr., Kärnefelt, A. Thell, Elix et J.-S. Hur, gen. nova MycoBank no.: MB 813896.

Thallus areolate, orange to orange reddish, sorediate. Apothecia zeorine, bright brownish red or brownish orange. Cortex of thalline exciple palisade paraplectenchymatous, true exciple paraplectenchymatous with well-developed matrix. Constituents: anthraquinones of the parietin chemosyndrome and O-methylvioxanthin.

Type species: Tayloriella erythrosticta (Taylor) S. Y. Kondr., Kärnefelt, A. Thell, Elix, J. Kim, A. S. Kondratiuk et J.-S. Hur. - Synonym: Caloplaca erythrosticta (Taylor) Zahlbr., Cat. Lich. Univ. 7: 116 (1930). Type: Swan River, on bark, coll.: J. Drummond (holotype: FH, isotype: BM). Basionym: Lecanora erythrosticta Taylor, J. Bot. (Hooker) 6: 161 (1847).

Thallus of very small or poorly developed areoles, orange to orange reddish brown, corticolous, sorediate, usually richly fertile. Soralia rather rare, from punctiform and rounded, to crater-like, often forming a sorediose mass covering the entire thallus. Soredia sometimes becoming isidioid. Apothecia zeorine, usually very abundant, bright brownish red or brownish orange. True exciple paraplectenchymatous with well-developed matrix. Cortex of thalline exciple palisade paraplectenchymatous (with rounded or spherical cells). Ascospores bipolar, long and narrow, with broad septa. Constituents: anthraquinones of the parietin chemosyndrome and O-methylvioxanthin. 
Etymology: The name Tayloriella honours the English botanist Thomas Taylor (1775-1848) who described the type species of the genus.

Taxonomic notes: Tayloriella differs from Caloplaca in having an areolate thallus containing anthraquinones, in a palisade paraplectenchymatous cortical layer, and in lacking a thick palisade cortical layer on the underside of the thalline exciple of apothecia, and in its phylogenetic position within the Brownlielloideae.

Tayloriella is similar to the Northern Hemisphere genus Flavoplaca of subfamily Xanthorioideae, but differs in its distribution, being restricted to the Australian continent, and its phylogenetic position in the Brownlielloideae.

The genus Tayloriella is presently monotypic, however, some Caloplaca species are candidates for to this genus pending molecular studies, such as 'Caloplaca' microphyllina (Tuck.) Hasse.

Thelliana S. Y. Kondr., Kärnefelt, Elix et J.-S. Hur, gen. nova

MycoBank no.: MB 813897.

Thallus crustose, areolate, dull brownish yellow to dull brownish orange. Areoles plane to concave with edges folded upwards, with sparse soredia or punctiform, bright yellow soralia. Cortical layer paraplectenchymatous. Apothecia biatorine.

Type species: Thelliana pseudokiamae S. Y. Kondr., Kärnefelt, Elix et J.-S. Hur.

Thallus crustose, areolate, dull brownish yellow to dull brownish orange, with very sparse brighter yellow blastidia or punctiform soralia, apothecia rare. Areoles plane to concave with edges folded upwards, becoming somewhat thicker and densely aggregated, especially along the rock crevices, with sparse soredia or punctiform, bright yellow soralia or blastidia. Blastidia very small and rarely seen. Cortical layer paraplectenchymatous. Apothecia biatorine.

Etymology: The generic name honours our friend and colleague, the Swedish lichenologist Arne Thell, for his contributions to lichenology in general, and for his important collections from the Southern Hemisphere.

Distribution: This genus is only known from South Australia.

Taxonomic notes: Thelliana is similar to the genera Squamulea and Flavoplaca, but differs in the morphology and anatomy of the thallus and thalline areoles, the latter being plane or concave with edges folded upwards, and in its position in the Brownlielloideae. In contrast, Squamulea and Flavoplaca belong to the Xanthorioideae. 
Thelliana pseudokiamae S. Y. Kondr., Kärnefelt, Elix et J.-S. Hur, spec. nova

MycoBank no.: MB 813898.

Similar to Squamulea kiamae, but differs in having smaller thalli, thalline areoles and isidiate blastidia, and in lacking distinct rosettes of radiating thalline lobes.

Type: Australia, South Australia, $12 \mathrm{~km} \mathrm{SW}$ of Quorn on the road to Port Augusta, ca $400 \mathrm{~m}$ alt., $32^{\circ} 25.72^{\prime} \mathrm{S}, 137^{\circ} 58.26^{\prime} \mathrm{E}$, on rock surface, coll.: I. Kärnefelt, 17.01.1999 (holotype: LD 1101337).

Thallus crustose, consisting of aggregations of plane, more or less flattened or rounded areoles with \pm undulating, raised margins, brownish yellow, with very sparse brighter yellow blastidia or punctiform soralia and rare apothecia. Areoles $0.4-1(-1.5) \mathrm{mm}$ long, and $0.4-0.7 \mathrm{~mm}$ wide, plane and entire becoming thinner towards the margins, with a flat upper surface and undulating margins, often grouped into aggregations, but soon becoming much larger, to $1(-1.5) \mathrm{mm}$ wide/across and somewhat thicker and with distinct, transverse cracks in the centre to $0.1 \mathrm{~mm}$ wide, and with margins often raised and undulate; areoles becoming somewhat thicker and densely aggregated, especially along the rock crevices.

Cortical layer paraplectenchymatous. Upper surface dull and matt to shiny, brownish yellow to dull brick-yellowish, blastidia or soralia bright yellowish. Rarely forming a blastidiose, seen only at higher magnification $(70-120 \times)$ at margins of areoles; soralia-like formations punctiform to $0.1 \mathrm{~mm}$ wide, up to 3-5 per areole, rarely observed. Blastidia very small and hardly seen, 25-30 $\mu \mathrm{m}$ diam., when blastidia isidioid to 30-50 $\mu \mathrm{m}$ diam., seen on areole edges or at the areole on the substrate surface.

Apothecia $0.2-0.3 \mathrm{~mm}$ diam., only juvenile apothecia seen, biatorine, disc and proper margin concolorous, reddish orange, proper margin 0.03-0.05 $\mathrm{mm}$ wide, thin but well developed, distinctly raised above the disc, thalline margin not observed. Mature asci and ascospores not seen.

This species occurs on rock surfaces or in rock crevices, associated with Caloplaca montisfracti, Filsoniana aff. scarlatina, Buellia sp., Acarospora spp., Verrucaria sp., as well as Xanthoparmelia sp., and several lichens with cyanobionts.

Etymology: The species name reflects the similarity of this species to Squamulea kiamae.

Distribution: At present known only from the type collection.

Taxonomic notes: The thalli of both Thelliana pseudokiamae and Squamulea kiamae are brownish-yellowish in colour and have brighter yellowish blastidia and transverse cracks in the centre of the thalline areoles. However, T. pseu- 
dokiamae differs in having smaller thalline areoles $(0.4-1(-1.5) \mathrm{mm}$ long and 0.4-0.7 mm wide vs. $0.7-1.8 \mathrm{~mm}$ long and $1.5-1.2 \mathrm{~mm}$ wide), smaller isidiate blastidia (ca $50 \mu \mathrm{m}$ diam. vs. $50-70(-100) \mu \mathrm{m}$ wide), in having blastidia throughout rather than just in the centre of thallus (the 1-2 mm wide peripheral zone usually lacks blastidia in S. kiamae), in not forming distinct rosettes of radiating thalline lobes, as well as in its position in the Brownlielloideae.

Juvenile thalli of T. pseudokiamae are very similar to Filsoniana scarlatina with which it often co-occurs, but it differs in having broader areoles (i.e.: $0.4-1(-1.5) \mathrm{mm}$ vs. $0.2-0.5 \mathrm{~mm}$ wide) with characteristic cracks and undulating, often raised margins. It also differs in having blastidia, very rare apothecia (common in F. scarlatina), and in its position in the Brownlielloideae (vs. member of the Teloschistoideae).

The plane, thin, juvenile thalline areoles of T. pseudokiamae resemble those of Flavoplaca cranfieldii, but it differs in having a much darker dull brownish yellow to dull brownish orange coloured thallus, in having rather sparse soredia or blastidia (vs. a better developed sorediose mass in F. cranfieldii), in forming much thicker aggregations and wider range of variation in size and thickness of thalline areoles, and in its position in the Brownlielloideae (vs. the member of the Xanthorioideae).

Thelliana pseudokiamae which grows side by side with Neobrownliella montisfracti, differs in having dull brownish yellow coloured of thallus (vs. greyish yellow), sessile apothecia, much thicker and larger thalline areoles and blastidia, and in its position in the Brownlielloideae (vs. the member of the Teloschistoideae).

The Australian species Caloplaca kiamae S. Y. Kondr. et Kärnefelt was placed in the genus Squamulea in subfamily Xanthorioideae following ITS nrDNA sequence investigations of the type material (Arup et al. 2013a). However, subsequent phylogenetic analyses of ITS and LSU nrDNA and 12S SSU mtDNA established that it belonged to Filsoniana in subfamily Teloschistoideae (Kondratyuk et al. 2013c). However, these data were not based on type material of Caloplaca kiamae and a re-examination of this specimen showed, in addition, morphological differences from Squamulea kiamae (see above).

\section{New combinations}

Brownliella kobeana (Nyl.) S. Y. Kondr., Kärnefelt, A. Thell, Elix, J. Kim, A. S. Kondratiuk et J.-S. Hur, comb. nova [MycoBank no.: MB 813899]. - Basionym: Lecanora kobeana Nyl., Lich. Japon. 36 (1890).

Fulgogasparrea appressa (Wetmore et Kärnefelt) S. Y. Kondr., Elix, Kärnefelt et A. Thell, comb. nova [MycoBank no.: MB 813900]. - Basionym: Caloplaca appressa Wetmore et Kärnefelt, Bryologist. 10(2): 233 (1998). 
Lazarenkoella zoroasteriorum (S. Y. Kondr. et M. Haji Moniri) S. Y. Kondr., Kärnefelt, A. Thell, Elix, J. Kim, A. S. Kondratiuk et J.-S. Hur, comb. nova [MycoBank no.: MB 813932]. - Basionym: Caloplaca zoroasteriorum S. Y. Kondr. et M. Haji Moniri, in Kondratyuk et al., Acta Bot. Hung. 55(1-2): 56 (2013).

Neobrownliella brownlieae (S. Y. Kondr., Elix et Kärnefelt) S. Y. Kondr., Elix, Kärnefelt et A. Thell, comb. nova [MycoBank no.: MB 813901]. - Basionym: Caloplaca brownlieae S. Y. Kondr., Elix et Kärnefelt, in Lumbsch et al., Phytotaxa 18: 28 (2011).

Neobrownliella montisfracti (S. Y. Kondr. et Kärnefelt) S. Y. Kondr., Elix, Kärnefelt et A. Thell, comb. nova [MycoBank no.: MB 813902]. - Basionym: Caloplaca montisfracti S. Y. Kondr. et Kärnefelt, Bibl. Lichenol. 95: 370 (2007).

Raesaeneniana maulensis (S. Y. Kondr. et J.-S. Hur) S. Y. Kondr., Elix, Kärnefelt et A. Thell, comb. nova [MycoBank no.: MB 813903]. - Basionym: Marchantiana maulensis S. Y. Kondr. et J.-S. Hur, in Kondratyuk et al., Acta Bot. Hung. 56(1-2): 108 (2014).

Streimanniella burneyensis (S. Y. Kondr. et Kärnefelt) S. Y. Kondr., Kärnefelt, A. Thell, Elix, J. Kim, A. S. Kondratiuk et J.-S. Hur, comb. nova [MycoBank no.: MB 813904]. - Basionym: Caloplaca burneyensis S. Y. Kondr. et Kärnefelt, Bibl. Lichenol. 100: 235 (2009).

Streimanniella kalbiorum (S. Y. Kondr. et Kärnefelt) S. Y. Kondr., Kärnefelt, A. Thell, Elix, J. Kim, A. S. Kondratiuk et J.-S. Hur, comb. nova [MycoBank no.: MB 813905]. - Basionym: Caloplaca kalbiorum S. Y. Kondr. et Kärnefelt, Bibl. Lichenol. 96: 158 (2007).

Streimanniella michelagoensis (Elix, S. Y. Kondr. et Kärnefelt) S. Y. Kondr., Kärnefelt, A. Thell, Elix, J. Kim, A. S. Kondratiuk et J.-S. Hur, comb. nova [MycoBank no.: MB 813924]. - Basionym: Caloplaca michelagoensis Elix, S. Y. Kondr. et Kärnefelt, Bibl. Lichenol. 100: 262 (2009).

Streimanniella seppeltii (S. Y. Kondr. et Kärnefelt) S. Y. Kondr., Kärnefelt, A. Thell, Elix, J. Kim, A. S. Kondratiuk et J.-S. Hur, comb. nova [MycoBank no.: MB 813926]. - Basionym: Caloplaca seppeltii S. Y. Kondr. et Kärnefelt, Bibl. Lichenol. 100: 267 (2009).

Tarasginia tomareeana (S. Y. Kondr. et Kärnefelt) S. Y. Kondr., Kärnefelt, A. Thell, Elix, J. Kim, A. S. Kondratiuk et J.-S. Hur, comb. nova [MycoBank no.: MB 813927]. - Basionym: Caloplaca tomareeana S. Y. Kondr. et Kärnefelt, Bibl. Lichenol. 95: 379 (2007).

Tarasginia whinrayi (S. Y. Kondr. et Kärnefelt) S. Y. Kondr., Kärnefelt, A. Thell, Elix, J. Kim, A. S. Kondratiuk et J.-S. Hur, comb. nova [MycoBank no.: MB 813928]. - Basionym: Caloplaca whinrayi S. Y. Kondr. et Kärnefelt, Bibl. Lichenol. 95: 381 (2007). 
Tayloriella erythrosticta (Taylor) S. Y. Kondr., Kärnefelt, A. Thell, Elix, J. Kim, A. S. Kondratiuk et J.-S. Hur, comb. nova [MycoBank no.: MB 813929)]. Basionym: Lecanora erythrosticta Taylor, J. Bot. (Hooker) 6: 161 (1847).

Acknowledgements - We thank Hidetoshi Nagamasu (Kyoto, Japan) and László Lőkös (Budapest, Hungary) for the loan of some taxa of the Faurie collection (KYO, Japan), Mahroo Haji Moniri (Mashhad, Iran) and Gintaras Kantvilas (Hobart, Australia) for help in providing samples for sequencing and to Teuvo Ahti (Helsinki, Finland) for valuable comments on the manuscript. This work was supported in part by The State Agency on Science, Innovations and Information of Ukraine (M317-2011-409, M111-2012-409 and M40-2013-409) for SK, and by The Forest Science \& Technology Projects (No. S111212L030100) provided by the Korea Forest Service for JSH.

\section{REFERENCES}

Arup, U. and Akelius, E. (2009): Taxonomic revision of Caloplaca herbidella and C. furfuracea. - Lichenologist 41: 465-480. http://dx.doi.org/10.1017/S0024282909008780

Arup, U., Søchting, U. and Frödén, P. (2013a): A new taxonomy of the family Teloschistaceae. - Nordic J. Bot. 31: 16-83. http://dx.doi.org/10.1111/j.1756-1051.2013.00062.x

Arup, U., Søchting, U. and Frödén, P. (2013b): Addendum to 'A new taxonomy of the family Teloschistaceae'. - Nordic J. Bot. 31: 256. http://dx.doi.org/10.1111/j.1756-1051.2013. 00295.x

Fedorenko, N. M., Stenroos, S., Thell, A., Kärnefelt, I. and Kondratyuk, S. Y. (2009): A phylogenetic analysis of xanthorioid lichens (Teloschistaceae, Ascomycota) based on ITS and mtSSU sequences. - Bibl. Lichenol. 100: 49-84.

Fedorenko, N. M., Stenroos, S., Thell, A., Kärnefelt, I., Elix, J. A., Hur, J.-S. and Kondratyuk, S. Y. (2012): Molecular phylogeny of xanthorioid lichens (Teloschistaceae, Ascomycota), with notes on their morphology. - Bibl. Lichenol. 108: 45-64.

Gardes, M. and Bruns, T. D. (1993): ITS primers with enhanced specificity for basidiomycetes - application to the identification of mycorrhizae and rusts. - Mol. Ecol. 2: 113-118.

Gaya, E., Högnabba, F., Holguin, Á., Molnár, K., Fernández-Brime, S., Stenroos, S., Arup, U., Søchting, U., Van den Boom, P., Lücking, R., Sipman, H. J. M. and Lutzoni, F. (2012): Implementing accumulative supermatrix approach for a comprehensive phylogenetic study of the Teloschistales (Pezizomycotina, Ascomycota). - Mol. Phyl. Evol. 63: 374-387. http://dx.doi.org/10.1016/j.ympev.2012.01.012

Hue, A. M. (1915): Lichenes novos vel melius cognitos exposuit. - Ann. Mycol. 13: 73-103.

Kärnefelt, I. (1989): Morphology and phylogeny in the Teloschistales. - Crypt. Bot. 1: 147-203.

Kondratyuk, S. Y., Kärnefelt, I., Elix, J. A. and Thell, A. (2007): New species of the genus Caloplaca in Australia. - Bibl. Lichenol. 95: 341-386.

Kondratyuk, S. Y., Kärnefelt, I., Thell, A., Elix, J. A., Kim, J., Kondratiuk, A. S. and Hur, J.-S. (2015): Tassiloa, a new genus in the Teloschistaceae (lichenized ascomycetes). - Graphis Scripta 27(1-2): 22-26.

Kondratyuk, S. Y., Fedorenko, N. M., Jeong, M.-H., Stenroos, S., Kärnefelt, I., Elix, J., Thell, A. and Hur, J.-S. (2013b): Phylogenetic analysis of lichen-forming fungi of the family Telo- 
schistaceae (Ascomycota) after nuclear and mitochondrial DNA sequences. - In: Kondratyuk, S. Y. (ed.): Molecular phylogeny and modern taxonomy of terrestrial sporen plants. Nauk. dumka, Kiev, pp. 7-57.

Kondratyuk, S., Jeong, M.-H., Yu, N.-H., Kärnefelt, I., Thell, A., Elix, J. A., Kim, J., Kondratyuk, A. S. and Hur, J.-S. (2013c): Four new genera of teloschistoid lichens (Teloschistaceae, Ascomycota) based on molecular phylogeny. - Acta Bot. Hung. 55(3-4): 251-274. http://dx.doi.org/10.1556/ABot.55.2013.3-4.8

Kondratyuk, S. Y., Jeong, M.-H., Yu, N.-N., Kärnefelt, I., Thell, A., Elix, J. A., Kim, J., Kondratiuk, A. S. and Hur, J.-S. (2014a): A revised taxonomy for the subfamily Caloplacoideae (Teloschistaceae, Ascomycota) based on molecular phylogeny. - Acta Bot. Hung. 56(1-2): 93-123. http://dx.doi.org/10.1556/ABot.56.2014.1-2.10

Kondratyuk, S. Y., Kärnefelt, I., Thell, A., Elix, J. A., Kim, J., Jeong, M.-H., Yu, N.-H., Kondratiuk, A. S. and Hur, J.-S. (2014b): A revised taxonomy of the subfamily Xanthorioideae (Teloschistaceae, Ascomycota) based on molecular phylogeny. - Acta Bot. Hung. 56(1-2): 141-178. http://dx.doi.org/10.1556/ABot.56.2014.1-2.12

Kondratyuk, S. Y., Lőkös, L., Zarei-Darki, B., Haji Moniri, M., Tchabanenko, S. I., Galanina, I., Yakovchenko, L., Hooshmand, F., Ezhkin, A. K. and Hur, J.-S. (2013a): Five new Caloplaca species (Teloschistaceae, Ascomycota) from Asia. - Acta Bot. Hung. 55(1-2): 69-88. http://dx.doi.org/10.1556/ABot.55.2013.1-2.4

Kondratyuk, S. Y., Fedorenko, N. M., Jeong, M.-H., Yu, N.-N., Stenroos, S., Kärnefelt, I., Elix, J. A., Thell, A., Kim, J., Kondratyuk, A. S. and Hur, J.-S. (2013d): Phylogenetic analysis of lichen-forming fungi of the family Teloschistaceae (Ascomycota) after nuclear and mitochondrial DNA. - In: Problems of Experimental Botany: IX Kuprevich Reading. Tekhnologia, Minsk, pp. 3-64.

Lumbsch, H. T., Ahti, T., Altermann, S., Amo de Paz, G., Aptroot, A., Arup, U., Bárcenas Peña, A., Bawingan, P. A., Benatti, M. N., Betancourt, L., Björk, C. R., Boonpragob, K., Brand., M., Bungartz, F., Cáceres, M. E. S., Candan, M., Chaves, J. L., Clerc, P., Common, R., Coppins, B. J., Crespo, A., Dal-Forno, M., Divakar, P. K., Duya, M. V., Elix, J. A., Elvebakk, A., Frankhauser, J., Farkas, E., Itati-Ferraro, L., Fischer, E., Galloway, D. J., Gaya, E., Giralt, M., Goward, T., Grube, M., Hafellner, J., Hernández, J. E., Herrera Campos, M., Kalb, K., Kärnefelt, I., Kantvilas, G., Killmann, D., Kirika, P., Knudsen, K., Komposch, H., Kondratyuk, S. Y., Lawrey, J. D., Mangold, A., Marcelli, M. P., McCune, B., Messuti, M. I., Michlig, A., González, R. M., Moncada, B., Naikatini, A., Nelsen, M. P., Øvstedal, D. O., Palice, Z., Papong, K., Parnmen, S., PérezOrtega, S., Printzen, C., Rico, V. J., Rivas Plata, E., Robayo, J., Rosabal, D., Ruprecht, U., Salazar Allen, N., Sancho, L., Santos de Jesus, L., Santos Vieira, T., Schultz, M., Seaward, M. R. D., Sèrusiaux, E., Schmitt, I., Sipman, H. J. M., Sohrabi, M., Søchting, U., Søgaard, M. Z., Sparrius, L. B., Spielmann, A., Spribille, T., Sutjaritturakan, J., Thammathaworn, A., Thell, A., Thor, G., Thüs, H., Timdal, E., Truong, C., Türk, R., Umaña Tenorio, L., Upreti, D. K., van den Boom, P., Vivas Rebuelta, M., Wedin, M., Will-Wolf, S., Wirth, V., Wirtz, N., Yahr, R., Yeshitela, K., Ziemmeck, F. and Lücking, R. (2011): One hundred new species of lichenized fungi: a signature of undiscovered global diversity. - Phytotaxa 18: 1-137. http://dx.doi.org/10.11646/phytotaxa.189.1.4

Martin, M. P. and Winka, K. (2000): Alternative methods of extracting and amplifying DNA from lichens. - Lichenologist 32: 189-196. http://dx.doi.org/10.1006/lich. 1999.0254

Miadłikowska, J., Kauff, F., Högnabba, F., Oliver, J. C., Molnár, K., Fraker, E., Gaya, E., Hafellner, J., Hofstetter, V., Gueidan, C., Otálora, M. A., Hodkinson, B., Kukwa, M., Lücking, R., Björk, C., Sipman, H. J. M., Burgaz, A. R., Thell, A., Passo, A., Myllys, 
L., Goward, T., Fernández-Brime, S., Hestmark, G., Lendemer, J., Lumbsch, H. T., Schmull, M., Schoch, C. L., Sérusiaux, E., Maddison, D. R., Arnold, A. E., Lutzoni, F. and Stenroos, S. (2014): A multigene phylogenetic synthesis for the class Lecanoromycetes (Ascomycota): 1307 fungi representing 1139 infrageneric taxa, 317 genera and 66 families. - Mol. Phyl. Evol. 79: 132-168. http://dx.doi.org/10.1016/j. ympev.2014.04.003

Søchting, U., Søgaard, M. Z., Elix, J. A., Arup, U., Elvebakk, A. and Sancho, L. G. (2014): Catenarina (Teloschistaceae, Ascomycotina), a new Southern Hemisphere genus with 7-chlorocatenarin. - Lichenologist 46: 175-187. http://dx.doi.org/10.1017/S0024 28291300087X

Steiner, M. and Poelt, J. (1982): Caloplaca sect. Xanthoriella, sect. nov: Untersuchungen über die "Xanthoria lobulata-Gruppe" (Lichenes, Teloschistaceae). - Pl. Syst. Evol. 140: $151-177$.

Swofford, D. L. (2002): PAUP. Phylogenetic analysis using parsimony. Ver. 4.0b.10. - Sinauer Associates, Sunderland, Massachusetts.

Vilgalys, R. and Hester, M. (1990): Rapid genetic identification and mapping of enzymatically amplified ribosomal DNA from several Cryptococcus species. - J. Bacteriol. 172(8): 4238-4246.

White, T. J., Bruns, T., Lee, S. and Taylor, J. (1990): Amplification and direct sequencing of fungal ribosomal RNA genes for phylogenetics. - In: Innis, M. A., Gelfand, D. H., Sninsky, J. J. and White T. J. (eds): PCR protocols: a guide to methods and applications. Academic Press, New York, pp. 315-322. 